\title{
Analisis Perbedaan Hasil Belajar IPA Siswa Kelas VII SMP Negeri 1 Muaro Jambi
}

\author{
Radias Ependi ${ }^{1}$, Nur Ika Sandi Pratiwi ${ }^{2}$ \\ ${ }^{1}$ SMAN 4 Tanjung Jabung Timur, Tanjung Jabung Timur, Jambi, Indonesia \\ ${ }^{2}$ Pendidikan Fisika, Universitas Jambi, Jambi, Indonesia
}

\section{Article Info}

Article history:

Received Jun 28, 2020

Revised Agu 4, 2020

Accepted Sep 5, 2020

\section{Keywords:}

Hasil Belajar

IPA

Siswa SMP

\begin{abstract}
ABSTRAK
Tujuan Penelitian: Tujuan dari penelitian ini adalah untuk mengetahui perbedaan hasil belajar IPA di kelas VII SMPN 1 Muaro Jambi.

Metodologi: Penelitian ini adalah penelitian kuntitatif dengan menggunakan analisis komparasional. Instrumen yang diguna berupa tes yang dibagikan kepada siswa dengan sampel 54 siswa yaitu terdiri dari 27 siswa dari kelas VIIA dan 27 siswa untuk kelas VIIB dengan populasi seluruh siswa SMPN 1 Muaro Jambi. Analisis data dalam penelitian ini menggunakan jenis penelitian kuantitatif dengan menggunakan program SPSS untuk mencari uji prasyarat yang meliputi: uji normalitas, dan uji homogenitas. Serta uji hipotesis yaitu uji Independent Samples T-test.

Temuan utama: Dalam penelitian diperoleh $t_{\text {hitung }}$ lebih kecil dari $t_{\text {tabel }}$ $(2,00665 \leq 8,405)$ dan nilai sig (2-tailed) Independent T-test adalah 0,000 . Itu berarti ada perbedaan yang signifikan antara rata-rata skor hasil belajar IPA kelas VII C dan kelas VII D atau hasil uji Independent T-test skor hasil belajar IPA menujukkan bahwa ada perbedaan yang signifikan antara data hasil belajar IPA kelas VII C dan kelas VII D.
\end{abstract}

Keterbaruan penelitian: Keterbaruan pada penelitian ini instrument yang digunakan oleh peneliti serta subjek yang digunakan.

This is an open access article under the CC BY-NC license

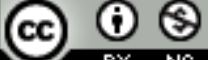

Corresponding Author:

Nur Ika Sandi Pratiwi,

Pendidikan Fisika, Universitas Jambi

Jl. Jambi-Ma. Bulia KM 15, Muaro Jambi, 36361, Jambi, Indonesia.

Email: nurikapratiwi026@gmail.com

\section{PENDAHULUAN}

Pendidikan adalah bidang yang cukup strategis digunakan sebagai media dalam pengembangan sumber daya manusia yang unggul dan berkarakter [1-3]. Pendidikan juga dapat diartikan sebagai suatu upaya pengolahan yang dilakukan oleh seseorang untuk mendapatkan pengetahuan, keterampilan, dan kebiasaan dalam hidup [4]. Pendidkan memegang peran penting dalam meningkatkan kualitas sumber daya manusia yang akan memberikan pengaruh terhadap kemajuan pembangunan bangsa [5, 6]. Untuk dapat mewujudkan pendidikan yang berkualitas diperlukan perjuangan, karena selama prosesnya tidak selamanya dapat berjalan dengan mulus sesuai dengan apa yang diinginkan [7]. Upaya yang dapat dilakukan dalam bidang pendidikan untuk mencetak SDM yang berkualitas dapat dilakukan dengan cara membiasakan membentuk budaya berfikir kritis pada siswa dalam proses pembelajarannya [8]. Untuk meningkatkan kualitas pendidikan di Indonesia, juga harus didukung oleh kualitas tenaga kependidikannya [9, 10]. Kompetensi guru merupakan salah satu factor penting yang menentukan keberhasilan proses pembelajaran. 
Proses pembelajaran adalah kegiatan yang dirancang untuk membantu seseorang mempelajari suatu kemampuan atau nilai yang baru [11]. Belajar adalah proses mendapatkan informasi dan nilai-nilai dalam suatu pengelolaan system [12]. Informasi tersebut dapat berupa ide, gagasan, ilmu pengetahuan yang dikemas menarik sehingga siswa tertarik untuk belajar dan aktif untuk mencari jawaban-jawaban dari segala masalah yang dihadapinya [13].

Pendidikan di indonesia terdapat beberapa jenjang pendidikan yaitu Sekolah Dasar, Sekolah Mnenegah Pertama (SMP), Sekolah Menengah Atas (SMA), dan jenjang pendidikan perguruan tinggi. Mata pelajaran IPA terdapat pada sekolah tingkat sekolah menegah pertama dan sebelumnya juga sudah dipelajari pada tingkat sekolah dasar. Pada dasarnya IPA terbentuk atas dasar produk ilmiah, proses ilmiah, dan sikap siswa [14]. Mata pelajaran IPA merupakan pembelajaran yang ruang lingkup cakupannya lebih kepada alam sekitar dan lingkuanganya, melalui mata pelajaran IPA dapat diperoleh kemampuan siswa dalam melakukan eksperimen, pengamatan, dan teori yang memberikan penjelasan mengenai gejala-gejala yang ada dalam kehidupan sehari-hari [15-17]. Mata pelajaran IPA di tingkat SMP terutama yang memiliki kontribusi untuk menjadikan peserta didik mampu menjadi generasi yang memiliki sikap ilmiah dalam kehidupan maupun lingkungannya [18]. Oleh sebab itu sangat penting bagi setiap peserta didik untuk mempelajari sains dengan baik. Pada pembelajaran IPA siswa dapat diperkenalkan dengan ke dunia sains dalam kehidupan mereka sehari-hari, membaca buku, menggunakan media digital untuk memperoleh informasi yang berkaitan dengan sains dan melakukan studi observasuional tentang alam [19].

IPA diperlukan dalam kehidupan sehari-hari untuk memenuhi kebutuhan manusia melalui pemecahan masalah-masalah yang dapat diidentifikasikan, penerapan IPA perlu dilakukan secara bijaksana guna menjaga dan memelihara kelestarian lingkungan [20]. Dengan memahami lingkungan disekitar tempatnya tinggal diharapkan peserta didik mampu mengembangkan keterampilan, wawasan dan kesadaran teknologi dalam kaitannya dengan pemanfaatannya dalam kehidupan sehari-hari [21]. Mengingat pentingnya pelajaran IPA di Sekolah Menengah Pertama (SMP), maka di dalam pelaksanaannya diperlukan guru yang mempunyai kemampuan dalam mengelola proses pembelajaran agar hasil belajar peserta didik dapat optimal [22]. Namun, pada kenyataannya pembelajaran IPA di SMP selama ini lebih menekankan pada hafalan materi dan kurang memfasilitasi peserta didik agar memiliki hasil belajar yang maksimal [23]. Peserta didik dipaksa untuk mengingat berbagai informasi tanpa dituntut untuk memahami dan menemukan informasi tersebut berdasarkan potensinya. Guru belum melaksanakan pembelajaran secara aktif dan kreatif melibatkan siswa dikelas. Dalam proses pembelajaran IPA masih sering ditemukan pembelajaran yang bepusat pada guru sehingga keterlibatan siswa selama proses pembelajaran masih kurang [24]. Siswa masih banyak menunggu disuap oleh guru daripada mencari dan menemukan pengetahuan sendiri. Siswa hanya mendengarkan, mencatat kemudian hanya mengerjakan soal latihan, yang menyebabkan pembelajaran menjadi monoton sehingga siswa Sekolah Menengah Pertama beranggapan bahwa mata pelajaran IPA itu sulit. Sehingga hal ini mempengaruhi hasil belajar yang diperoleh oleh siswa. Dimana hasil belajar adalah perubahan secara positif setelah siswa mengikuti proses pembelajaran, selain itu juga siswa mengalami perubahan dalam bentuk tingkat penguasaan siswa terhadap pengetahuan dan keterampilan yang diperoleh setelah belajar.

Sehubungan dengan hal tersebut maka peneliti tertarik untuk mengukur perbndingan hasil belajar IPA kelas VII di Kabupaten Muaro Jambi, khususnya di SMPN 1 Muaro Jambi. Hasil penelitian ini diharapkan dapat dijadikan acuan untuk peneliti selanjutnya atau dapat menjadi pedoman bagi guru. Tujuan dilaksanakannya penelitian ini adalah untuk mengetahui perbedaan hasil belajar siswa kelas VII di SMPN 1 Muaro Jambi.

\section{METODE PENELITIAN}

Penelitian ini merupakan penelitian kuantitatif dengan menggunakan analisis komparasional. Dimana analisis komparasional yang dimaksuda alah analisis statistic yang membandingkan dua sampel yang tidak saling berhubungan maupun antar dua sampel yang saling berhubungan, baik dengan sampel besar maupun sampel kecil [25]. Adapun variable dalam penelitian ini menggunakan 2 variabel yaitu variable dependen dan variable independen. Variable independen penelitian ini yaitu kelas VII, sedangkan variable independen pada penelitian ini adalah harsil belajar siswa SMPN 1 Muaro Jambi. Penelitian ini dilaksanakan di Sekolah Menengah Pertama (SMP) Negeri 1 Muaro Jambi. Populasi dalam penelitian ini adalah seluruh siswa - siswi SMPN 1 Muaro Jambi. Sedangkan sampel atau bagian kecil yang diambil untuk mewakili populasinya yaitu Kelas VII C dan Kelas VII D, kelas VII C terdiri dari 27 siswa dan jumlah kelas VII D terdiri dari 27 siswa, sehingga jumlah total sampel yang digunakan yaitu 54 siswa.

Instrument pada penelitian ini menggunakan instrument soal. Dimana soal yang digunakan mengadaptasi dari buku "Fisika Smart" [26], serta soal dari penelitian [27]. Dalam instrument tes yang digunakan pada penelitian ini terdapat 30 soal dengan alternatif jawaban untuk pilihan ganda yaitu A, B, C, dan D. Penskoran yang digunkan adalah untuk jawaban benar diberi skor 1 dan jawaban salah diberi skor 0.

Analisis Perbedaan Hasil Belajar IPA Siswa Kelas VII SMP Negeri 1 Muaro Jambi (Radias Ependi) 
Dalam pengumpulan data, kegiatan pertama yang dilakukan adalah memilih siswa berdasarkan kategori yang diberikan oleh peneliti, kemudian memberikan soal kepada siswa, kemudian data yang diperoleh dianalisis dengan menggunakan aplikasi SPSS 23 untuk melihat perbedaan hasil belajar siswa. Adapun perosedur pengumpulan data penelitian ini sesuai dengan diagram berikut:
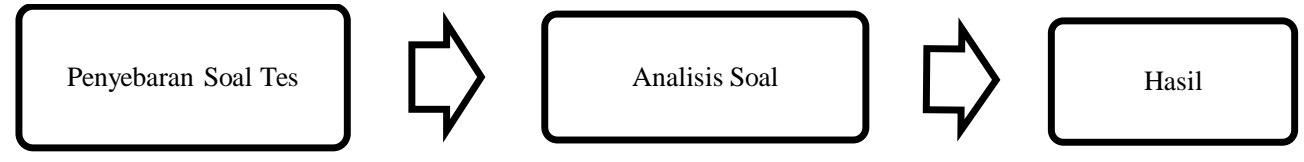

Gambar 1. Prosedur Penelitian

Pada penelitian ini sebelum dilakukan uji Hipotesis terlebih dahulu dilakukan uji prasyarat yaitu uji normalitas dan uji homogenitas. Uji normalitas untuk mengetahui apakah data penelitian yang diperoleh berdistribusi normal atau tidak.persyaratan distrbusi data merupakan unsur yang snagat penting dalam menentukan pemilihan uji statistic karena beberapa analisis memiliki persyaratan tertentu antara lain normalitas, homogenitas, dan uji t. uji normalitas dimaksudkan untuk memperlihatkan bahwa sampel yang diambil dari populasi yang berdistribusi normal. Uji normalitas dapat dilakuakan dengan menggunakan uji Kolmogorov Smirnov. Langkah pengujian komogorov-smirnov dilakuakan dengan menggunakan SPSS 23 dengan melihat hasil output dari uji normalitas dengan taraf signifikansi 5\%. Data berdistribusisi normal jika probabilitas atau $\mathrm{P}>0.05$. selanjutnya yaitu uji homogenitas, uji homogenitas digunakan untuk memperlihatkan bahwa dua atau lebih kelompok data sampel berasal dari populais yang memiliki variasi yang sama. Langkah pengujian homogenitas dilakukan dengan menggunakan SPSS 23 dengan hasil output dari homogenitas denga taraf signifikansi 5\%. Data dikatakan berpopulasi homogeny dari kelompok penelitian jika probabilitas atau $\mathrm{P}>00.5$.

Setelah dilakukan uji normaitas dan homogenitas selanjutnya yaitu uji hipotesis (uji T). uji t akan membandingkan rata-rata dari dua grup yang tidak berhubungan satu dengan yang lain dengan tujuan apakah kedua grup tersebut mempunyai rata-rata yang sama ataukah tidak [28]. Adapun hipotesis yang digunakan dalam pengujian hipotesis data angket karakter toleransi dengan menggunakan uji Independent $T$ test adalah:

Ho : Tidak ada perbedaan yang signifikan antara rata-rata skor soal dua kelas yaitu kelas VII C dan kelas VII D ( Ho: $\left.\mu_{1}=\mu_{2}\right)$.

$\mathrm{Ha}$ : Ada perbedaan yang signfikan antara rata-rata skor soal dua kelas yaitu kelas VII C dan kelas VII D ( Ho: $\left.\mu_{1} \neq \mu_{2}\right)$.

Dimana kriteria pengambilan keputusan dari hasil Independent $T$ test untuk skor soal antara kelompok kelas VII C dan kelas VII D adalah: jika Sig $\leq$ 0,05 maka Ho ditolak dan Ha diterima, artinya ada perbedaan yang signifikan antara rata-rata hasil belajar IPA kelas VII C dan kelas VII D. Dan jika nilai Sig $\geq$ 0,05 maka Ho diterima dan Ha ditolak, artinya tidak ada perbedaaan yang signifikan antara hasil belajar IPA kelas VII C dan kelas VII D.

\section{HASIL DAN PEMBAHASAN}

Ada atau tidaknya perbedaan hasil belajar siswa dapat dilihat melalui analisis data dengan teknik tertentu. Analisis data dilakukan dengan menggunakan uji prasyarat, dan uji hipotesis. Uji prasyarat yang digunakan meliputi uji normalitas data skor hasil belajar IPA dan uji homogenitas data hasil beajar IPA siswa. Teknik analisis uji hipotesis yang dilakukan dalam penelitian ini tergantung pada hasil uji prasyarat yang dilakukan. Melalui uji hipotesis, ada atau tidaknya perbedaan hasil belajar IPA siswa kelas VII C dan kelas VII D pada materi besaran dan satuan dapat diketahui.

\section{Uji Prasyarat}

Adapun uji prasayarat yang dilakukan dengan menggunakan SPSS 23. Yang hasilnya adalah sebagai berikut:

\section{- Uji Normalitas}

Uji normalitas skor hasil belajar IPA digunakan untuk mengetahui apakah distribusi sebuah data mengikuti dan mendekati distribusi normal, yakni distribusi data dengan bentuk lonceng (bell shaped) [29]. Uji normalitas dilakukan untuk data skor hasil belajar IPA dari masing-masing kelas yaitu kelas VII C dan kelas VII D. Uji normalitas data skor hasil belajar IPA dilakukan dengan menggunakan Kolmogorov-Smirnov 
Test karena jumlah sampel kecil dan bukan data berkelompok. Hipotesis untuk uji normalitas data skor hasil belajar adalah:

Ho : sebaran data tidak berbeda dengan kurva normal atau data normal.

Ha : sebaran data berbeda dengan kurva normal atau data tidak normal.

Taraf signifikansi yang digunakan adalah 0,05 dengan tingkat kepercayaan 95\%. Kriteria pengambilan keputusan dari hasil uji normalitas data skor hasil belajar IPA menggunakan KolmogorovSmirnov Test pada kelompok kelas VII C dan kelas VII D adalah jika harga sig. (2-tailed) KolmogorovSmirnov Test $\geq 0,05$, maka Ho diterima atau Ha ditolak, artinya sebaran data skor hasil belajar IPA sesuai dengan kurva normal. Adapun hasil penghitungan uji normalitas untuk data skor hasil belajar IPA pada kelas VII C dan kelas VII D menggunakan Kolmogorov-Smirnov Test dengan bantuan program SPSS 23 dapat dilihat pada table 1 .

Tabel 1. Hasil Uji Normalitas Kelas VII A dan kelas VII B

\begin{tabular}{lrrrrrr}
\hline \multicolumn{9}{c}{ Test of Normality $^{-}$} & \multicolumn{3}{c}{ Shapiro-Wilk } \\
\hline & \multicolumn{3}{c}{ Kolmogorov-Smirnov } \\
\hline Statistic & Df & \multicolumn{1}{c}{ Sig } & Statistic & Df & Sig \\
\hline Kelas VII C & .166 & 27 & .055 & .908 & 27 & .020 \\
\hline
\end{tabular}

Table 1 merupakan hasil penghitungan uji normalitas untuk data skor hasil belajar IPA pada kelas VII C dan kelas VII D dengan bantuan SPSS 23. Tabel tersebut memperlihatkan nilai hasil uji normalitas yang menunjukkan nilai sig. (2-tailed) Kolmogorov-Smirnov Test adalah 0,055 untuk kelas VII C dan 0,200 untuk kelas VII D. Nilai $0,055 \geq 0,05$ dan Nilai $0,200 \geq 0,05$, maka dapat disimpulkan bahwa Ho diterima dan Ha ditolak atau data berdistribusi normal.

\section{- Uji Homogenitas}

Analisis yang dilakukan selanjutnya adalah menguji homogenitas data skor hasil belajar IPA. Uji homogenitas ini merupakan uji yang diguanakan untuk memberikan informasi bahwa data penelitian masingmasing kelompok data berasal dari populasi yang tidak berbeda jauh keragamannya [30]. Hasil uji homogenitas yang baik apabila hasil uji tersebut simpangan estimasinya mendekati angka nol. Pengujian homogenitas antara data skor hasil belajar IPA kelas VII C dan kelas VII D dilakukan dengan menggunakan Levene's Test. Hipotesis untuk uji homogenitas antara data hasil belajar IPA kelas VII C dan kelas VII D ini adalah:

Ho : Tidak ada perbedaan varian antara hasil belajar IPA kelas VII C dan kelasVII D atau data hasil belajar kedua kelompok adalah homogen (Ho: $\sigma_{1}{ }^{2}=\sigma_{2}{ }^{2}$ ).

$\mathrm{Ha}$ : Ada perbedaan varian antara hasil belajar kelas IPA VII C dan kelas VII D atau data skor soal kedua kelas adalah tidak homogen ( $\mathrm{Ha}:{\sigma_{1}}^{2} \neq{\sigma_{2}}^{2}$ ).

Kriteria pengambilan keputusan dari hasil uji homogenitas ini adalah jika harga sig. (2-tailed) Levene's Test $\geq 0,05$, maka Ho atau Ha ditolak, artinya tidak ada persebaran varian antara dua data skor hasil belajar IPA kelas VII C dan kelas VII D atau data skor hasil belajar IPA kedua kelas tersebut adalah homogen. Dengan kata lain kedua kelompok memiliki kemampuan yang sama. Jika harga sig. (2-tailed) Levene's Test $<0,05$, maka Ho ditolak atau Ha diterima, artinya ada persebaran varian antara data skor hasil belajar IPA kelas VII C dan kelas VII D atau data skor hasil belajar IPA kedua kelas tersebut adalah tidak homogen. Dengan kata lain kedua kelas tersebut memiliki kemampuan yang tidak sama. Adapun hasil penghitungan uji homogenitas untuk data skor hasil belajar IPA pada kelas VII C dan kelas VII D menggunakan Levene's Test dengan bantuan program SPSS 23 dapat dilihat pada table 2.

Tabel 2. Hasil Uji Homogenitas Skor Hasil Belajar IPA kelas VII C dan VII D

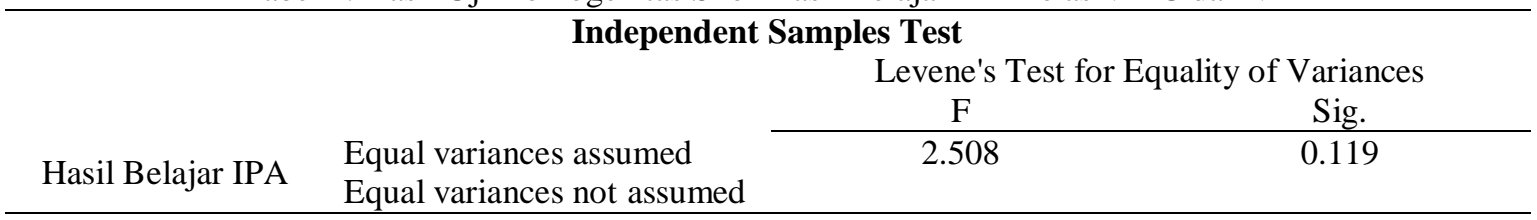

Table 2 menunjukkan hasil penghitungan uji homogenitas antara data skor hasil belajar kelas VII C dan VII D yang dapat dilihat pada harga signifikansi kolom Levene's Test. Hasil uji homogenitas menunjukkan harga sig(2-tailed) sebesar 0,119. Nilai 0,119 $\geq 0,05$, maka dapat disimpulkan bahwa Ho diterima dan Ha ditolak. Hasil tersebut juga dapat dinyatakan bahwa tidak ada perbedaan varian antara data hasil belajar IPA kelas VII C dan kelas VII D atau skor hasil belajar IPA kedua kelas homogen, dengan kata 
lain kedua kelas mempunyai kemampuan yang sama. Hasil uji homogenitas antara data skor hasil belajar kedua kelas menunjukkan homogen, maka dapat disimpulkan dengan uji statistic Independent T-test yang diambil adalah data pada baris pertama output SPSS yaitu equal variances assumed.

\section{Uji Hipotesis}

Uji Independent Samples T-test

Uji Independent Samples T-test skor hasil belajar dilakukan dengan tujuan untuk mengetahui perbedaan rata-rata antara skor hasil belajar IPA kelas VII C dan kelas VII D. hipotesis yang digunakan dalam uji Independent Samples T-test untuk kellas VII A dan kelas VII B adalah:

Ho : Tidak ada perbedaan yang signifikan antara rata-rata skor hasil belajar IPA kelas VII C dan kelas VII D $\left(\right.$ Ho: $\left.\mu_{1}=\mu_{2}\right)$.

Ha : Ada perbedaan yang signfikan antara rata-rata skor hasil belajar IPA kedua kelas yaitu kelas VII C dan kelas VII D (Ho: $\mu_{1} \neq \mu_{2}$ ).

Taraf signifikan yang digunakan adalah 0,05 dengan tingkat kepercayaan 95\%. Kriteria pengambilan keputusan pada hasil uji Independent Samples T-tests adalah sebagai berikut:

1. Jika sig (2-tailed) Independent $T$-test $\geq 0,05$, maka Ho diterima dan Ha ditolak, artinya tidak ada perbedan yang signifikan antara hasil belajar IPA kelas VII A dan kelas VII B.

2. Jika sig (2-tailed) Independent T-test $\leq 0,05$, maka Ho ditolak atau Ha diterima, artinya ada perbedaan yang signifikan antara hasil belajar IPA kelas VII A dan kelas VII B.

Adapun Hasil penghitungan uji Independent T-test untuk data skor hasil belajar IPA antara kelas VII C dan kelas VII D dengan menggunakan SPSS 23 dapat dilihat pada table 3.

Tabel 3. Hasil Uji Independent T-test skor Hasil belajar IPA Kelas VII C dan kelas VII D.

\begin{tabular}{|c|c|c|c|c|c|c|c|c|}
\hline \multicolumn{9}{|c|}{ t-test for Equality of Means } \\
\hline & & \multirow[t]{2}{*}{$\mathrm{T}$} & \multirow[t]{2}{*}{ Df } & \multirow{2}{*}{$\begin{array}{l}\text { Sig. (2- } \\
\text { Tiled) }\end{array}$} & \multirow{2}{*}{$\begin{array}{c}\text { Mean } \\
\text { Diefferenc } \\
\mathrm{e}\end{array}$} & \multirow{2}{*}{$\begin{array}{c}\text { Std. Error } \\
\text { Differenc } \\
\text { e }\end{array}$} & \multicolumn{2}{|c|}{$\begin{array}{l}\text { 95\% Confidence } \\
\text { Interval of the } \\
\text { Difference }\end{array}$} \\
\hline & & & & & & & $\begin{array}{l}\text { Lowe } \\
\mathrm{r}\end{array}$ & Upper \\
\hline Hasil & Equal variances assumed & 8.405 & 52 & 0.000 & 24.047 & 2.861 & 18.306 & 29,788 \\
\hline $\begin{array}{l}\text { belajar } \\
\text { IPA }\end{array}$ & $\begin{array}{c}\text { Equal variances not } \\
\text { assumed }\end{array}$ & 8.405 & 49.336 & 0.000 & 24.047 & 2.861 & 18.298 & 29,795 \\
\hline
\end{tabular}

Table 3 memperlihatkan bahwa F hitung pada tingkat kepercayaan 95\% untuk hasil uji Independent T-test data skor hasil belajar IPA siswa kelas VII. Harga F untuk equal variance assumed adalah 2,508 dengan nilai Independent T-test sig (2-tailed) 0.000. Nilai sig (2-tailed) Independent T-test adalah 0,000 $\leq 0,05$, maka Ho ditolak atau Ha diterima artinya ada perbedaan yang signifikan antara hasil belajar IPA kelas VII C dan kelas VII D. Kesimpulan hasil uji Independent T-test menujukkan bahwa ada perbedaan yang signifikan antara data hasil belajar IPA kelas VII C dan kelas VII D. Perbedaan rata-rata dapat dilihat dikolom Mean Difference yaitu sebesar 24,047.

Selain itu hasil analisis penelitian juga didukung oleh uji hipotesis menggunakan SPSS 23 dimana hasil analisis menunjukkan bahwa harga sig $0,000 \leq 0,05$, maka Ho ditolak, dan Ha diterima artinya ada perbedaan yang signifikan antara rata-rata skor hasil belajar IPA pada kelas VII C dan kelas VII D. Secara umum kelas VII C (Mean = 84,13; SE = 1,772) memiliki rata-rata skor yang lebih tinggi jika dibandingkan dengan skor hasil belajar IPA kelas VII D ( Mean =60,09; SE = 2,249 ). Dari hasil tersebut diketahui bahwa kelas VII C mempunyai rata-rata nilai yang jauh lebih tinggi dibandingkan dengan rata-rata nilai hasil belajar IPA kelas VII D. Artinya, kelas VII C mempunyai tingkat kecerdasan yang lebih tinggi dibandingkan dengan kelas VII D. Hasil belajar IPA adalah kemampuan-kemampuan yang dimiliki atau dikuasai siswa setelah ia menerima pengalaman belajarnya [31]. Perbedaan hasil belajar antara kedua kelas ini bisa dipengaruhi oleh banyak factor, seperti kemampuan siswa dalam belajar setelah menerima materi pembelajaran, kemampuan guru dalam mendiagnosis kesulitan belajar dan pemanfaatan media belajar untuk meningkatkan keberhasilan siswa dalam belajar serta cara pengelolaan kelas [32]. Pengelolaan kelas merupakan bagian penting dari peran kepemimpinan guru secara keseluruhan dan tidak dapat dipisahkan dari aspek-aspek lain dari ajaran. Perencanaan yang baik, penghargaan dan praktik hukuman, pengembangan kegiatan kelas, melibatkan siswa dalam pendekatan berpusat pada siswa, memperhatikan motivasi siswa, atau tugas-tugas pembelajaran yang berbeda. Semua elemen dalam persektif titik pengelolaan kelas untuk membangun lingkungan belajar yang positif untuk melibatkan siswa dalam belajar sehingga dapat meminimalkan masalah perilaku dan gangguan 
dalam pelajaran. Faktor lain yang mempengaruhi hasil belajar siswa yaitu minat belajar individu, minat siswa yang tinggi menyebabkan belajar siswa lebih mudah dan cepat, kemudian motivasi belajar siswa [33].

\section{KESIMPULAN}

Berdasarkan hasil analisis data penelitian dan pengujian hipotesis dapat disimpulkan bahwa: Dari hasil perhitungan uji hipotesis dengan uji $t$ diperoleh $t_{\text {hitung }}$ lebih kecil dari $t_{\text {tabel }}(2,00665 \leq 8,405)$ dan nilai sig (2-tailed) Independent T-test adalah $0,000 \leq 0,05$. Maka, Ho ditolak dan Ha diterima, artinya ada perbedaan yang signifikan antara rata-rata skor hasil belajar IPA kelas VII C dan kelas VII D atau hasil uji Independent T-test skor hasil belajar IPA menujukkan bahwa ada perbedaan yang signifikan antara data hasil belajar IPA kelas VII C dan kelas VII D. Nilai rata-rata hasil belajar IPA kelas VII C diperoleh sebesar 84,13 dengan Standar Error of Mean 1,772 dan nilai rata-rata hasil belajar kelas VII D sebesar 60,09 dengan Standar Error of Mean 2,249. Dari data nilai rata-rata (mean) hasil belajar IPA yang dicapai siswa kelas VII C dan kelas VII D tersebut menunjukkan bahwa skor hasil belajar IPA kelas VII C mempunyai rata-rata nilai yang jauh lebih dinggi jika dibandingkan dengan hasil belajar IPA kelas VII D, atau dapat disimpulkan bahwa siswa di kelas VII C mempunyai tingkat kecerdasan yang lebih tinggi dibandingkan dengan siswa kelas VII D.

\section{UCAPAN TERIMA KASIH}

Selesainya tulisan ini tidak lepas dari bantuan berbagai pihak, untuk itu penulis ucapkan terima kasih kepada pada responden yang telah bersedia menjadi subjek dalam penelitian ini. Selanjutnya Penulis juga berterima kasih kepada para penyumbang sumber inspirasi yang telah memberikan inspirasi bagi penulis untuk mengutip atau menggunakan tulisannya sebagai sebuah referensi.

\section{REFERENSI}

[1] Astalini, D. A. Kurniawan, H. Parasdila and Irdianti, "Description of Science Process Skills' Physics Education Students at Jambi University in Temperature and Heat Materials," The Education Review, vol. 5, no. 2, pp. 485 498, 2018.

[2] M. D. W. Ernawati, Haryanto and S. C. Nababan, "Analisis Penerapan Model Pembelajaran Kooperatif Number Head Together (NHT) dan Pengaruhnya Terhadap Hasil Belajar Siswa pada Materi Struktur Atom di Kelas SMKN 3 Kota Jambi," J. Ind Soc. Integ. Chem, vol. 9, no. 1, pp. 45-53, 2017.

[3] R. A. Z. Islami, Nahadi and A. Permanasari, "Hubungan Literasi Sains Dan Keprcayaan Diri Siswa Pada Konsep Asam Basa.," Jurnal Penelitian dan Pembelajaran IPA, vol. 1, no. 1, pp. 16-25, 2015.

[4] M. Naswir, Haryanto and Ferawati, "Analisis Keterlaksanaan Model Pembelajaran Inkuiri Terbimbing Materi Sifat Koligatif Larutan dan Pengaruhnya Terhadap Kemampuan Berpikir Kreatif Siswa Kelas XII IPA SMA Islam AlFalah Kota Jambi," J. Indo. Soc. Integ. Chem, vol. 9, no. 2, pp. 43-51, 2016.

[5] Asrial, D. A. Kurniawan, R. Perdana and W. Kurniawan, "Identification Attitudes of Learners on Physics Subject," Integrated Science Education Journal (ISEJ), vol. 1, no. 2, pp. 46-50, 2020.

[6] E. Wati, M. Ilyas and E. D. Sulistyowati, "Pengembangan Media Mobile Learning Dalam Pembelajaran Menulis Deskripsi Pada Siswa Kelas X SMK," Jurnal Ilmu Budaya, vol. 1, no. 4, pp. 291-304, 2017.

[7] Ratnawati and Marimin, "Pengaruh Kesiapan Belajar Minat Belajar, Motivasi Belajar, dan Sikap Siswa Terhadap Keaktifan Belajar Siswa Jurusan Administrassi Perkantoran Pada Mata Diklat Produktif AP di SMK Negeri 2 Semarang," Economic Education Analysis Journal, vol. 3, no. 1, pp. 77-82, 2014.

[8] Fujika, E. Anggreini and R. S. Budiarti, "Analisis Kemampuan Berfikir Kritis Siswa SMAN 5 Kota Jambi Melalui Pembelajaran Berbasis Masalah Pada Konsep Pencemaran Lingkungan," BIodik, vol. 1, no. 1, pp. 1-10, 2015.

[9] Zulfani, Asrial and M. Yamin, "Pengaruh Pendekatan Pembelajaran dan Kreativitas Terhadap Pemahaman Konsep IPA di Sekolah Dasar," Tekno-Pedagogi, vol. 2, no. 2, pp. 28-40, 2012.

[10] Asrial, Syahrial, D. A. Kurniawan, F. Chan, R. Septianingsih and R. Perdana, "Multimedia innovation 4.0 in education: E-Modul Ethnoconstructivism," Universal Journal of Educational Research , vol. 7, no. 10, pp. 2098 2107, 2019.

[11] Abdurrahman, Gardjito and R. S. Budiarti, "Pengembangan Lembar Kegiaan Siswa Berbasis Penemuan Terbimbing Pada Materi Struktur Dan Fungsi Jaringan," Biodik, vol. 1, no. 1, pp. 1-8, 2015.

[12] R. Darussyamsu, R. Wahyuni, R. Fitri, M. Fadilah and M. Mukhtar, "Senior High School Biology Teachers' Perception Towards Evolution Learning," Jurnal Pembelajaran dan Penelitian IPA, vol. 5, no. 2, pp. 185-201, 2019.

[13] R. S. Budiarti and A. Sadikin, "Pengaru Kwartet Animalia Dengan Model TGT Terhadap Pemahaman Materi Taksonomi Hewan Siswa SMAN 8 Kota Jambi," Biodik, vol. 1, no. 1, pp. 1-9, 2015. 
[14] Astalini, D. A. Kurniawan, Melsayanti and Destilanti, "Sikap Terhadap Mata Pelajaran IPA se-Kabupaten Muaro Jambi.," Lentera Pendidikan, vol. 21, no. 2, pp. 214-227, 2018.

[15] Astalini and D. A. Kurniawan, "Pengembngan Instrumen Sikap Siswa Sekolah Menengah Pertama Terhadap Mata Pelajaran IPA," Jurnal Pendidikan Sains, vol. 7, no. 1, pp. 1-7, 2019.

[16] Tanti, D. A. Kurniawan, R. Perdana and O. H. Wiza, "Comparison of Students' Attitudes toward Natural Sciences in Rural Middle Schools in Jambi Province," JURNAL TA’DIB,, vol. 23, no. 1, pp. 63-73, 2020.

[17] Astalini, H. Pathoni, D. A. Kurniawan and N. Kurniawan, "The Correlation Between Attitudes and Decipline Toward Science of Secondaru School," Jurnal Pendidikan Sains, vol. 7, no. 1, pp. 9-14, 2019.

[18] E. Sulistiani, R. S. Budiarti and Muswita, "Analisis Kemampuan Berpikir Kritis Siswa Lintas Minat Pada Pembelajaran Biologi Kelas X IIS SMA Negeri 11 Kota Jambi," Biodik, vol. 2, no. 1, pp. 1-7, 2016.

[19] Astalini, H. Pathoni, D. A. Kurniawan and N. Kurniawan, "he Correlation Between Attitudes and Decipline Toward Science of Secondaru School,," Jurnal Pendidikan Sains, vol. 7, no. 1, pp. 9-14, 2019.

[20] N. Adilah, "Perbedaan Hasil Belajar IPA Melalui Penenrapan Metode Mind Map dengan Metode Ceramah," Indonesian Journal of Primary Education, vol. 1, no. 1, pp. 98-103, 2017.

[21] S. Widodo, "Pengembangan Keterampilan Berpikir Krtiis Peserta Didik Dengan Menggunakan Model Pembelajaran Berbasis Masalah (Problem Based Learning) Melalui Isu-Isu Sosial Ekonomi Pasca Penggenanga Waduk Jatigede Dalam Pembelajaran IPS di SMPN 2 Wado Kabupaten Sumedan," International Journal Pedagogy of Social Studies, vol. 1, no. 2, pp. 1-14, 2016.

[22] M. K. Nasution, "Penggunaan Metode Pmebleajran Dalam Peningkatan Hasil Belajar Siswa," STUDIA DIDAKTIKA: Jurnal Ilmiah Bidang Pendidikan, vol. 11, no. 1, pp. 9-16, 2017.

[23] M. Naswir, Hayanto and Ferawati, "Analisis Keterlaksanaan Model Pembelajaran Inkuiri Terbimbing Materi Sifat Koligatif Larutan dan Pengaruhnya Terhadap Kemampuan Berpikir Kratif Siswa Kelas XII IPA SMA Islam AlFalah Kota Jambi," J. Indo. Soc. Integ. Chem, vol. 9, no. 2, pp. 45-51, 2016.

[24] Subhan, S. D. Fatmaryanti and N. Hidayati, "Kekatifan Bertanya Siswa Dengan Menggunakan Model Pembelajaran AKtif Tipe Card Sortpad Kelas X Madrasah Aliyah Wathoniyah Islamiyah Karangduwur," Radiasi, vol. 2, no. 1, pp. 18-20, 2013.

[25] G. Pramesti, Kupas Tuntas Data Penelitian dengan SPSS 22, Jakarta: PT Elex Media Kumputindo, 2014.

[26] W. K. Santso, Fisika Smart SMP, Jakarta: Bhuana Ilmu Populer, 2015.

[27] D. A. Supriyadi, "Peningkatan Hasil Belajar Materi Besaran dan Satuan Menggunakan Macromedia Flash 8 Pada Siswa kelas VII di MTs NU. 05 Sunan Katong Kaliwungu Tahun Pelajaran 2015/2016," Fakultas Ilmu Tarbiyah dan Keguruan Universitas Islam Negeri Walisongo, Semarang, 2015.

[28] Sudjono, Pengantar Statistika Pendidikan., Jakarta: PT Raja Grafindo Persada, 2004.

[29] S. Santoso, Statistik Multivariat: Konsep dan Aplikasi dengan SPSS, Jakarta: PT Elex Media Kompitundo, 2017.

[30] F. Ismail, Statistika Untuk Penelitian Pendidkan dan Ilmu-Ilmu Sosial, Jakarta: Prenamedia Grup, 2018.

[31] N. Sudjana, Penialain hasil Proses Belajar Mangajar, Bandung: Remaja Rosdakarya, 2016.

[32] H. D. Pingge and M. N. Wangid, "Faktor Yang Mempengaruhi Hasil Belajar Siswa Sekolah Dasar Di Kecamata Kota Tambolaka," Jurnal JPSD (Jurnal Pendidikan Sekolah Dasar), vol. 2, no. 1, pp. 146-167, 2016.

[33] K. T. Aritonang, "Minat dan Motivasi dalam Meningkatkan Hasil Belajar Siswa," Jurnal Pendidikan Penabur, vol. 10, no. 7, pp. 11-21, 2008.

[34] Bungin, Metodologi Penelitian Kuantitatif: Komunikasi, Ekonomi , dan Kebijakan public serta ilmu-ilmu soaial lainnya, Jakarta: Kencana, 2005.

[35] Muslim, "Pengaruh Pelaksanaan pendidikan Karakter Pada Mata pelajaran Sejarah Terhadap Sikap nasionalisme Siswa kelas XI MA Al Asror Semarang Tahun Ajaran 2012/2013," Jurusan Pendidikan Sejarah Fakultas Ilmu Sosial Universitas Negeri Semarang, Semarang, 2013.

[36] Narlan and D. T. Juniar, Statistika Dalam Penjas: Aplikasi Praktis dalam Penlitian Pendidikan Jasmani, Yogyakarta: Deepublish, 2018 